\title{
Influence of Amino Acid Compositions and Peptide Profiles on Antioxidant Capacities of Two Protein Hydrolysates from Skipjack Tuna (Katsuwonus pelamis) Dark Muscle
}

\section{Chang-Feng Chi ${ }^{1, *}$, Fa-Yuan Hu ${ }^{1}$, Bin Wang ${ }^{2, *}$, Zhong-Rui Li ${ }^{3}$ and Hong-Yu Luo ${ }^{2}$}

1 National Engineering Research Center of Marine Facilities Aquaculture, School of Marine Science and Technology, Zhejiang Ocean University, 1st Haidanan Road, Changzhi Island, Lincheng, Zhoushan 316022, China; E-Mail: moonriveryue@163.com

2 Zhejiang Provincial Engineering Technology Research Center of Marine Biomedical Products, School of Food and Pharmacy, Zhejiang Ocean University, 1st Haidanan Road, Changzhi Island, Lincheng, Zhoushan 316022, China; E-Mail: lisa8919@163.com

3 Division of Life Science, Hong Kong University of Science and Technology, Clear Water Bay, Kowloon, Hong Kong, China; E-Mail: zlibb@ust.hk

* Authors to whom correspondence should be addressed;

E-Mails: chichangfeng@hotmail.com (C.-F.C.); wangbin4159@hotmail.com (B.W.);

Tel.: +86-580-255-4818 (C.-F.C.); +86-580-255-5085 (B.W.); Fax: +86-580-255-4818 (C.-F.C.); $+86-580-255-4781$ (B.W.).

Academic Editor: Colin Barrow

Received: 7 March 2015 / Accepted: 21 April 2015 / Published: 27 April 2015

\begin{abstract}
Influence of amino acid compositions and peptide profiles on antioxidant capacities of two protein hydrolysates from skipjack tuna (Katsuwonus pelamis) dark muscle was investigated. Dark muscles from skipjack tuna were hydrolyzed using five separate proteases, including pepsin, trypsin, Neutrase, papain and Alcalase. Two hydrolysates, ATH and NTH, prepared using Alcalase and Neutrase, respectively, showed the strongest antioxidant capacities and were further fractionated using ultrafiltration and gel filtration chromatography. Two fractions, Fr.A3 and Fr.B2, isolated from ATH and NTH, respectively, showed strong radical scavenging activities toward 2,2-diphenyl-1picrylhydrazyl radicals $\left(\mathrm{EC}_{50} 1.08 \% \pm 0.08 \%\right.$ and $0.98 \% \pm 0.07 \%$ ), hydroxyl radicals $\left(\mathrm{EC}_{50}\right.$ $0.22 \% \pm 0.03 \%$ and $0.48 \% \pm 0.05 \%$ ), and superoxide anion radicals $\left(\mathrm{EC}_{50} 1.31 \% \pm 0.11 \%\right.$ and $1.56 \% \pm 1.03 \%$ ) and effectively inhibited lipid peroxidation. Eighteen peptides from Fr.A3 and 13 peptides from Fr.B2 were isolated by reversed-phase high performance liquid
\end{abstract}


chromatography, and their amino acid sequences were determined. The elevated antioxidant activity of Fr.A3 might be due to its high content of hydrophobic and aromatic amino acid residues (181.1 and 469.9 residues/1000 residues, respectively), small molecular sizes (3-6 peptides), low molecular weights $(524.78 \mathrm{kDa})$, and amino acid sequences (antioxidant score 6.11). This study confirmed that a smaller molecular size, the presence of hydrophobic and aromatic amino acid residues, and the amino acid sequences were the key factors that determined the antioxidant activities of the proteins, hydrolysates and peptides. The results also demonstrated that the derived hydrolysates and fractions from skipjack tuna ( $K$. pelamis) dark muscles could prevent oxidative reactions and might be useful for food preservation and medicinal purposes.

Keywords: skipjack tuna (Katsuwonus pelamis); dark muscle byproduct; protein hydrolysate; peptide; antioxidant activity

\section{Introduction}

Oxidative deterioration is a prominent threat to the quality of lipid-containing foods that produces off-flavors and reduces the nutritive value and safety of the foods by forming secondary reaction products during processing and storage [1-3]. In addition, the generation of radicals, especially reactive oxygen species (ROS), during oxidative stresses can react with substances in the body, resulting in cellular damage and disorders [4,5]. Antioxidants can inhibit oxidative reactions by scavenging free radicals and interrupting the radical chain reaction of lipid peroxidation. Therefore, the elimination of ROS and other free radicals is considered one of the most important antioxidant mechanisms in food and biological systems. Synthetic antioxidants, such as butylated hydroxytoluene (BHT) and butylated hydroxyanisole (BHA), are used to overcome the deleterious effects induced by free radicals. However, their use has been strictly regulated due to potential health hazards $[6,7]$. Fortunately, antioxidant peptides obtained from food proteins can serve as potential substitutes for synthetic antioxidants because of their elevated activities and stabilities $[8,9]$.

Traditionally, dark muscle byproducts from the seafood industry are primarily used to produce lowmarket-value products, such as fishmeal and fertilizer, because of their dark color, oxidation, off-flavors and poor functional properties [10]. There are multiple options for recovering dark muscle byproducts and converting them to value-added products $[11,12]$. Among these possibilities, enzymatic hydrolysis is one of the most efficient methods for the high-value use of dark muscle byproducts [13,14], and some antioxidant peptides have been isolated and identified from the muscles of various aquatic species. Jiang et al. purified two antioxidant peptides (HDHPVC and HQKVC) from round scad muscle protein hydrolysate, and their studies indicated that the two novel peptides could be developed into antioxidant ingredients in functional foods [11]. Peptides of QWPAQ, FLHRP, and LMGQW, isolated from the protein hydrolysates of monkfish muscle [15], and LDK, WDR and PYFNK, isolated from the hydrolysates of Sphyrna lewini muscle protein $[3,16]$, were effective against lipid peroxidation and exhibited good scavenging activity on 2,2-diphenyl-1-picrylhydrazyl (DPPH) radicals (DPPH•), hydroxyl radicals $(\mathrm{HO} \bullet)$, and superoxide anion radicals $\left(\mathrm{O}_{2}^{-} \bullet\right.$ in dose-dependent manners. VCSV and 
CAAP from the protein hydrolysates of flounder fish muscle showed good scavenging activity against $\mathrm{DPPH} \bullet$ and high cytoprotective activities against 2,2-azobis-(2-amidinopropane) dihydrochloride without significant cytotoxicity and scavenged total reactive oxygen species in Vero cells [17]. Nonapeptide LGLNGDDVN, purified from the tryptic hydrolysates of conger eel muscle protein, effectively scavenged $\mathrm{HO} \cdot$ and carbon-centered radicals and performed better than the natural antioxidant, $\alpha$-tocopherol, for the prevention of lipid peroxidation in vitro [18]. DLDLRKDLYAN, from the protein hydrolysates of defatted skipjack roe, showed strong metal chelating activities as well as 2,2'-azino-bis(3-ethylbenzthiazoline)-6-sulfonic acid (ABTS) radical and singlet oxygen scavenging activities and could be further employed as a functional food ingredient [19]. The peptide LSGYGP, isolated from tilapia gelatin, could alleviate the UV-induced abnormal changes in antioxidant indicators, protect skin lipids and collagen, and repair the synthesis of endogenous collagen in a dose-dependent manner; thus, it could be a novel anti-photoaging agent from natural resources [20]. Hexapeptide WCTSVS, from the hydrolysates of the edible parts of the Indian squid, exhibited strong free radical scavenging, metal chelation and reducing power. It also exhibited no cytotoxic effects on breast cancer cells (MCF7) and scavenged reactive oxygen species at the cellular level under $\mathrm{H}_{2} \mathrm{O}_{2}$-induced stress [21,22]. These studies indicate that aquatic muscle proteins are high-quality raw materials that can be used for the preparation of antioxidant peptides. The peptides derived from the protein hydrolysates of seafood muscles could serve as potent antioxidants against oxidative stresses and be used as an efficient and safe additive in food processing.

China is among the world's largest producers and exporters of canned tuna. Skipjack tuna (K. pelamis) is the most viable commercial species in the tuna industry. In 2013, more than 100 tons of raw tuna were processed in Zhoushan City, Zhejiang Province of China. Approximately 50\% of the processed raw materials were considered industrial byproducts, such as dark muscle, head, skin, bones and viscera [23]. Recently, several studies have reported on the use of tuna byproducts through enzymatic hydrolysis [12,23-28]. Several bioactive peptides, including GDLGKTTTVSNWSPPKYKDTP, PVSHDHAPEY, PSDHDHE, VHDY, VKAGFAWTANQQLS, LPTSEAAKY and PMDYMVT, have been extracted from the protein hydrolysates of tuna frames [24], cooking juices [25], backbones [26], and dark muscles [27]. These studies provide useful information for the preparation of peptides from tuna byproducts and for converting these byproducts into value-added peptide products with significant functional and nutritional properties by enzymatic hydrolysis. However, more research must be performed to further utilize the dark muscles of tuna. Therefore, in the present study, skipjack tuna dark muscle (STDM) samples were hydrolyzed using five separate proteases. The two protein hydrolysates with the highest antioxidant activities were fractionated using ultrafiltration and gel filtration chromatography. The influence of amino acid compositions and peptide profiles on antioxidant activities of the resulting fractions was comparatively analyzed.

\section{Results and Discussion}

\subsection{Preparation of Protein Hydrolysates of STDM Using Five Proteases}

Radical scavenging assays are fast, convenient, and efficient in predicting the antioxidant activities of protein hydrolysates, their fractions, and purified peptides. Therefore, the relatively stable radicals 
$\mathrm{DPPH} \bullet, \mathrm{HO} \bullet$, and $\mathrm{O}_{2}^{-} \bullet$ have been widely used to test the ability and evaluate the antioxidant activity of compounds to act as free radical scavengers or hydrogen donors [7]. In addition, the degree of hydrolysis $(\mathrm{DH})$ could affect the molecular sizes and amino acid compositions of the peptides and thereby affect the biological activities of the peptides formed during hydrolysis. Therefore, the $\mathrm{DH}$ is an important parameter in determining the functional properties of protein hydrolysate preparations [29]. In this experiment, radical scavenging assays and the $\mathrm{DH}$ were used to determine the hydrolytic capacities of proteases on defatted STDM.

Defatted STDM samples were separately hydrolyzed with pepsin, trypsin, Neutrase, papain and Alcalase. The $\mathrm{DH}$ values and radical ( $\mathrm{DPPH} \bullet, \mathrm{HO} \bullet$, and $\mathrm{O}_{2}^{-} \bullet$ ) scavenging activities of the resulting hydrolysates were shown in Table 1 and Figure 1. After $4 \mathrm{~h}$ of hydrolysis, the Alcalase hydrolysate (ATH) showed a significantly higher DH value $(p<0.05)$ of $27.63 \% \pm 1.14 \%$ followed by the Neutrase hydrolysate $(\mathrm{NTH})(25.72 \% \pm 1.09 \%)$, whereas the trypsin hydrolysate showed a significantly lower DH value $(p<0.05)$ of $19.35 \% \pm 0.67 \%$. The DH curves were similar to those previously reported for the hydrolysates from zebra blenny proteins [30] and sole, squid [31], and cuttlefish skin gelatins [32].

The DPPH•, $\mathrm{HO} \bullet$, and $\mathrm{O}_{2}^{-}$scavenging activities of the five hydrolysates are shown in Table 1. ATH exhibited significantly higher $\mathrm{DPPH} \bullet, \mathrm{HO} \bullet$, and $\mathrm{O}_{2}^{-} \bullet$ scavenging activities $(p<0.05)$, with $\mathrm{EC}_{50}$ values of $4.54 \pm 0.43,1.27 \pm 0.12$, and $5.67 \pm 0.26 \mathrm{mg} / \mathrm{mL}$, respectively. NTH followed with $\mathrm{EC}_{50}$ values of $5.38 \pm 0.15,1.58 \pm 0.11$, and $6.38 \pm 0.53 \mathrm{mg} / \mathrm{mL}$, whereas the lowest radical scavenging activities were observed in the trypsin hydrolysates. This data trend was in agreement with the DH order of the five hydrolysates. Based on these results, ATH and NTH were selected for follow-up studies.

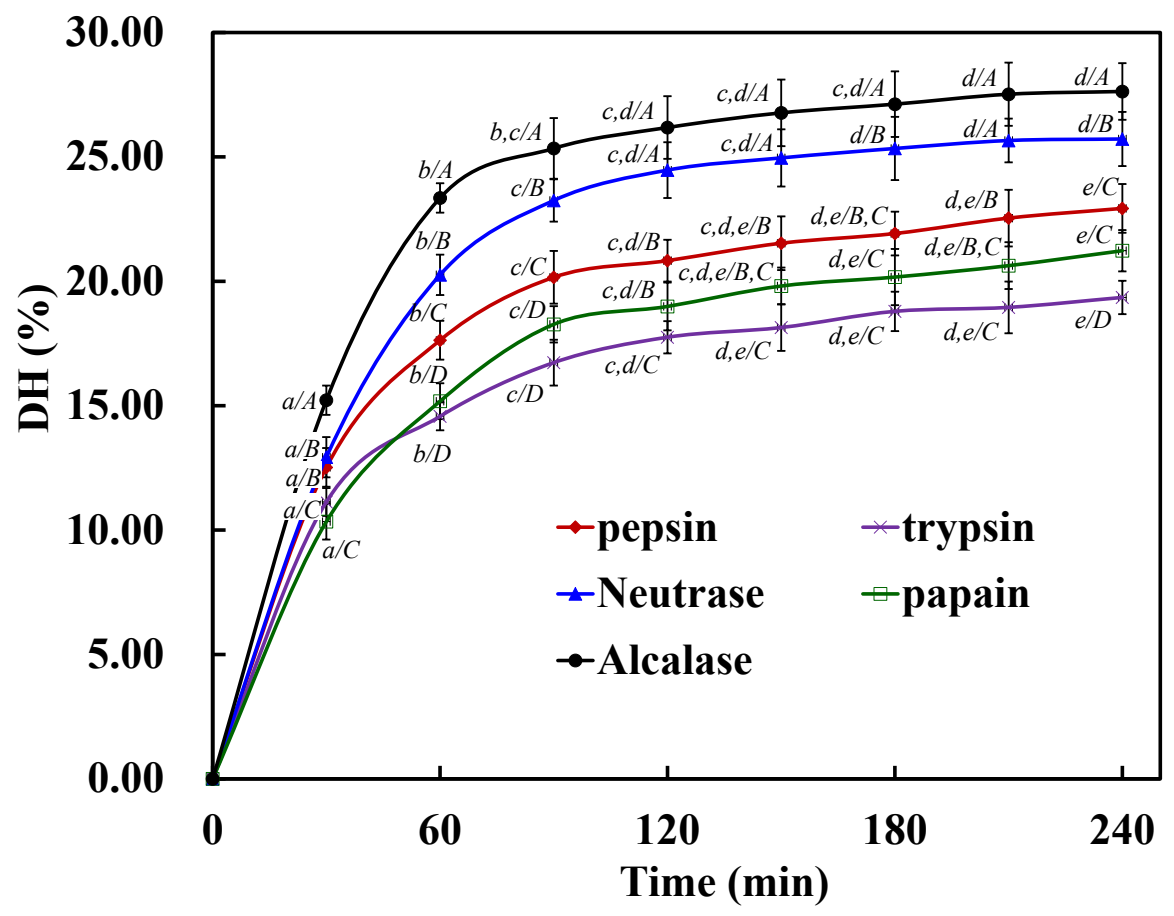

Figure 1. DH of protein hydrolysates of STDM using five proteases. All values mean \pm SD. $(a-e)$ Values with different letters indicated significant differences in the same sample at different times $(p<0.05)$; $(A-D)$ Values with different letters indicated significant differences in different samples at the same time $(p<0.05)$. 
Table 1. Radical (DPPH•, HO•, and $\mathrm{O}_{2}^{-} \bullet$ ) scavenging activities and the degree of hydrolysis $(\mathrm{DH}, \%)$ of the protein hydrolysates of STDM using five proteases.

\begin{tabular}{ccccc}
\hline \multirow{2}{*}{ Enzyme } & \multirow{2}{*}{ DH (\%) } & \multicolumn{3}{c}{ EC $_{\mathbf{5 0}}(\mathbf{m g} / \mathbf{m L})$ of Protein Hydrolysates } \\
\cline { 3 - 5 } & & $\mathbf{D P P H}^{\bullet}$ & HO• & $\mathrm{O}_{2}^{-}$ \\
\hline Pepsin & $22.93 \pm 0.98^{\mathrm{a}}$ & $7.09 \pm 0.37^{\mathrm{a}}$ & $2.37 \pm 0.09^{\mathrm{a}}$ & $7.65 \pm 0.42^{\mathrm{a}}$ \\
Trypsin & $19.35 \pm 0.67^{\mathrm{b}}$ & $9.36 \pm 0.51^{\mathrm{b}}$ & $4.09 \pm 0.16^{\mathrm{b}}$ & $9.37 \pm 0.40^{\mathrm{b}}$ \\
Neutrase & $25.72 \pm 1.09^{\mathrm{c}}$ & $5.38 \pm 0.15^{\mathrm{c}}$ & $1.58 \pm 0.11^{\mathrm{c}}$ & $6.38 \pm 0.53^{\mathrm{c}}$ \\
Papain & $21.23 \pm 0.83^{\mathrm{a}}$ & $8.65 \pm 0.57^{\mathrm{b}}$ & $3.42 \pm 0.23^{\mathrm{d}}$ & $8.66 \pm 0.48^{\mathrm{b}}$ \\
Alcalase & $27.63 \pm 1.14^{\mathrm{d}}$ & $4.54 \pm 0.43^{\mathrm{d}}$ & $1.27 \pm 0.12^{\mathrm{e}}$ & $5.67 \pm 0.26^{\mathrm{c}}$ \\
\hline
\end{tabular}

All values were the mean \pm standard deviation $(\mathrm{SD}) . \mathrm{EC}_{50}(\mathrm{mg} / \mathrm{mL})$ was defined as the concentration at which a sample caused a $50 \%$ decrease in the initial concentrations of $\mathrm{DPPH} \cdot, \mathrm{HO} \cdot$, and $\mathrm{O}_{2}^{-} \cdot$ (a-e) Values with different letters indicated significant differences in the same sample at different times $(p<0.05)$.

\subsection{Isolation of Antioxidant Peptides}

\subsubsection{Ultrafiltration (UF) Fractionation of ATH and NTH}

UF is a membrane filtration process in which forces pressure or concentration gradients lead to a separation through a semipermeable membrane. Currently, UF membrane technology has been of great importance for the purification, concentration, and fractionation of several products in various areas, such as the food, pharmaceutical, and biotechnology industries, and has been one of the best available techniques for the enrichment of peptides [33]. ATH-I (MW $>3 \mathrm{kDa})$ and ATH-II $(\mathrm{MW}<3 \mathrm{kDa})$ fractionated from ATH, and NTH-I (MW $>3 \mathrm{kDa})$ and NTH-II $(\mathrm{MW}<3 \mathrm{kDa})$ from NTH were prepared using a $3 \mathrm{kDa}$ molecular weight cut-off (MWCO) membrane. ATH, NTH and their four fractions scavenged $\mathrm{DPPH} \bullet, \mathrm{HO} \bullet$, and $\mathrm{O}_{2}^{-} \bullet$ in a concentration-dependent manner (data not shown), and their $\mathrm{EC}_{50}$ values are shown in Table 2.

The results indicated that ATH-II exhibited significantly higher antioxidant activity than ATH and ATH-I $(p<0.05)$, with EC50 values of $2.21 \pm 0.12,0.58 \pm 0.05$, and $2.74 \pm 0.11 \mathrm{mg} / \mathrm{mL}$ for DPPH , $\mathrm{HO} \bullet$, and $\mathrm{O}_{2}^{-} \bullet$, respectively. Similarly, NTH-II showed significantly higher antioxidant activity than NTH and NTH-I $(p<0.05)$, with EC $_{50}$ values of $3.09 \pm 0.23,0.85 \pm 0.06$, and $2.83 \pm 1.08 \mathrm{mg} / \mathrm{mL}$ for $\mathrm{DPPH} \bullet, \mathrm{HO} \bullet$, and $\mathrm{O}_{2}^{-} \bullet$, respectively. The results suggested that the type of peptide played a key role in the antioxidant activity of the protein hydrolysates and their fractions. The original hydrolysate was filtered with a $3 \mathrm{kDa}$ MWCO membrane, which removed high MW peptides. Therefore, the resultant hydrolysate fractions with high bioactivities were composed of low MW peptides [5,34]. These results agreed with the previous report that protein hydrolysates or peptides with lower MWs were observed to have higher antioxidant activities and more effectively interact with radicals, thus intervening in the oxidation process $[3,35]$. 
Table 2. Radical (DPPH•, $\mathrm{HO} \cdot$, and $\mathrm{O}_{2}^{-} \cdot$ ) scavenging activities of protein hydrolysates (ATH and NTH) and their fractions prepared by ultrafiltration and gel filtration chromatography.

\begin{tabular}{|c|c|c|c|}
\hline \multirow{2}{*}{ Sample } & \multicolumn{3}{|c|}{$\mathrm{EC}_{50}(\mathrm{mg} / \mathrm{mL})$} \\
\hline & DPPH• & HO• & $\mathbf{O}_{2}^{-} \bullet$ \\
\hline \multicolumn{4}{|c|}{ ATH and Its Fractions } \\
\hline ATH & $4.54 \pm 0.43^{\mathrm{a}}$ & $1.27 \pm 0.12^{\mathrm{a}}$ & $5.67 \pm 0.26^{\mathrm{a}}$ \\
\hline ATH-I & $7.06 \pm 0.63^{b}$ & $1.56 \pm 0.17^{\mathrm{b}}$ & $6.82 \pm 0.47^{b}$ \\
\hline ATH-II & $2.21 \pm 0.12^{\mathrm{c}, \mathrm{f}}$ & $0.58 \pm 0.05^{\mathrm{c}, \mathrm{d}}$ & $2.74 \pm 0.11^{\mathrm{c}}$ \\
\hline Fr.A1 & $3.27 \pm 0.24^{\mathrm{d}, \mathrm{e}}$ & $0.73 \pm 0.08^{\mathrm{d}, \mathrm{e}}$ & $3.54 \pm 0.26^{\mathrm{d}}$ \\
\hline Fr.A2 & $2.42 \pm 0.15^{\mathrm{f}}$ & $0.55 \pm 0.06^{\mathrm{c}, \mathrm{d}, \mathrm{f}}$ & $2.76 \pm 0.18^{\mathrm{c}}$ \\
\hline Fr.A3 & $1.08 \pm 0.08^{\mathrm{g}}$ & $0.22 \pm 0.05^{\mathrm{g}}$ & $1.31 \pm 0.11^{\mathrm{e}}$ \\
\hline Fr.A4 & $1.76 \pm 0.04^{\mathrm{c}}$ & $0.37 \pm 0.03^{\mathrm{f}, \mathrm{g}}$ & $1.69 \pm 0.09^{\mathrm{e}}$ \\
\hline \multicolumn{4}{|c|}{ NTH and Its Fractions } \\
\hline NTH & $5.38 \pm 0.15^{\mathrm{h}}$ & $1.58 \pm 0.11^{\mathrm{b}}$ & $6.38 \pm 0.53^{b}$ \\
\hline NTH-I & $8.16 \pm 0.42^{i}$ & $1.88 \pm 0.22^{\mathrm{h}}$ & $7.34 \pm 0.58^{f}$ \\
\hline NTH-II & $3.09 \pm 0.23^{\mathrm{d}}$ & $0.85 \pm 0.06^{\mathrm{e}, \mathrm{i}}$ & $2.83 \pm 0.18^{c}$ \\
\hline Fr.B1 & $3.74 \pm 0.24^{\mathrm{e}}$ & $1.09 \pm 0.12^{\mathrm{j}}$ & $3.36 \pm 0.32^{\mathrm{d}}$ \\
\hline Fr.B2 & $0.98 \pm 0.07^{\mathrm{g}}$ & $0.48 \pm 0.05^{\mathrm{c}, \mathrm{f}}$ & $1.56 \pm 0.13^{\mathrm{e}}$ \\
\hline Fr.B3 & $3.06 \pm 0.15^{\mathrm{d}}$ & $0.94 \pm 0.06^{\mathrm{i}, \mathrm{j}}$ & $2.35 \pm 0.22^{\mathrm{c}}$ \\
\hline
\end{tabular}

All values were the mean \pm standard deviation $(\mathrm{SD}) . \mathrm{EC}_{50}(\mathrm{mg} / \mathrm{mL})$ was defined as the concentration at which a sample caused a $50 \%$ decrease in the initial concentrations of $\mathrm{DPPH} \bullet, \mathrm{HO} \cdot$, and $\mathrm{O}_{2}^{-} \cdot(\mathrm{a}-\mathrm{j})$ Values with different letters indicated significant differences in the same sample at different times $(p<0.05)$.

\subsubsection{Gel Filtration Chromatography of ATH-II and NTH-II}

Gel filtration is a method that enables the separation of substances with different molecular dimensions, and it has been widely used to separate peptides from protein hydrolysates [36]. In this study, ATH-II and NTH-II were further purified on a Sephadex G-25 column (Figure 2). As shown in Figure 2A, ATH-II was subsequently separated into four subfractions (Fr.A1 to Fr.A4). Fr.A3 showed significantly higher radical scavenging activities than the other ATH-II subfractions $(p<0.05)$ did, with $\mathrm{EC}_{50}$ values of $1.08 \pm 0.08(\mathrm{DPPH} \bullet), 0.22 \pm 0.05(\mathrm{HO} \bullet)$, and $1.31 \pm 0.11 \mathrm{mg} / \mathrm{mL}\left(\mathrm{O}_{2}^{-} \bullet\right)($ Table 2$)$. NTH-II was divided into three subfractions (Fr.B1 to Fr.B3). Fr.B2 showed significantly stronger $\mathrm{DPPH} \bullet, \mathrm{HO} \bullet$, and $\mathrm{O}_{2}^{-} \bullet$ scavenging activities than the other two NTH-II subtractions $(P<0.05)$ did, with EC50 values of $0.98 \pm 0.07,0.48 \pm 0.05$, and $1.56 \pm 1.03 \mathrm{mg} / \mathrm{mL}$, respectively (Figure $2 \mathrm{~B}$ and Table 2). Moreover, the DPPH $\bullet, \mathrm{HO} \bullet$, and $\mathrm{O}_{2}^{-} \bullet$ scavenging activities of Fr.A3 were higher than those of Fr.B2. 

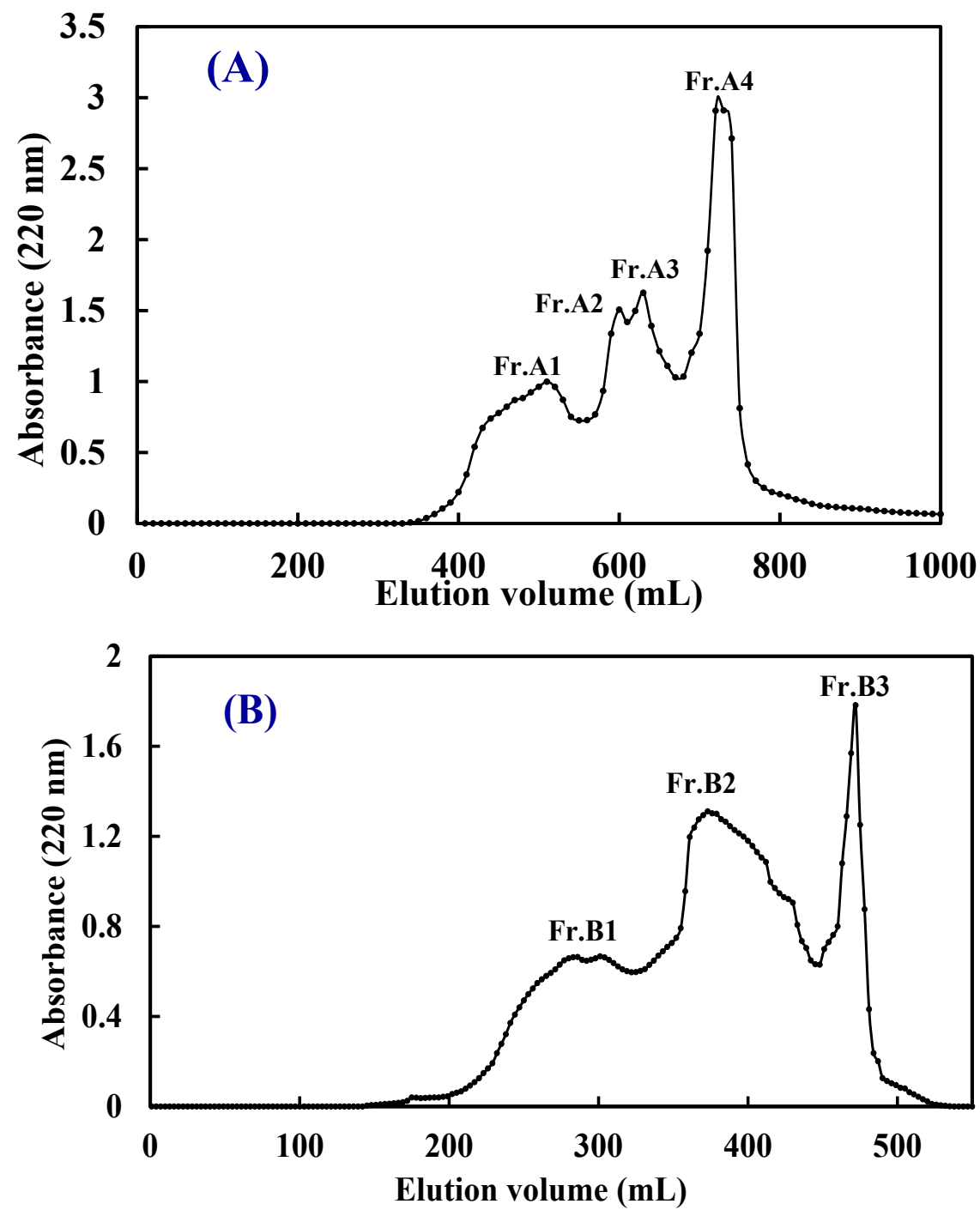

Figure 2. Elution profiles of ATH-II (A) and NTH-II (B) obtained by size exclusion chromatography on a Sephadex G-25 column.

\subsection{Amino Acid and Peptide Compositions of Fr.A3 and Fr.B2}

\subsubsection{Amino Acid Compositions of Fr.A3 and Fr.B2}

The amino acid composition of any food protein hydrolysate plays a significant role in various physiological activities, which has also been observed for the antioxidant activities of protein hydrolysates [37]. The amino acid profiles of defatted STDM, ATH, NTH, Fr.A3 and Fr.B2 are shown in Table 3. The amino acid compositions, hydrophobic amino acid contents, and aromatic amino acid contents of ATH and NTH are similar to those of defatted STDM, which was rich in Glu, Asp, Leu, and Ala but lacked Cys, Pro, Trp, and Tyr. These results indicated that the hydrolysis process did not significantly alter the profile of the amino acids [32]. However, the amino acid compositions of Fr.A3 and Fr.B2 were different from those of the defatted STDM and its hydrolysates. Additionally, the hydrophobic and aromatic amino acid contents of these fractions were significantly higher than those of ATH and NTH. Pownall et al. confirmed that the higher contents of hydrophobic and aromatic amino acids facilitated the radical scavenging and metal chelating activities of protein hydrolysate 
fractions from pea seeds (Pisum sativum L.) [38]. Himaya et al. reported that hydrophobic amino acids facilitated interactions with hydrophobic targets, such as the cell membrane, and thereby, enhanced the bioavailability [2]. Additionally, hydrophobic peptides can protect against macromolecular oxidation by donating photons to reactive radicals. Mendis et al. reported that the high potency of HGPLGPL as an antioxidant could be derived from hydrophobic amino acids, which may facilitate greater interaction between the peptide and fatty acids [13]. Furthermore, aromatic amino acids increased the antioxidant activities of peptides and protein hydrolysates because they easily donate protons to electron-deficient radicals and maintain their stabilities via resonance structures and enhance radical scavenging activities [8,38-40]. Therefore, the high hydrophobic and aromatic amino acid contents of Fr.A3 and Fr.B2 might be an important reason for their high antioxidant activities.

Table 3. Amino acid compositions of Defatted STDM, ATH, NTH, Fr.A3 and Fr.B2 (expressed as residues/1000 residues).

\begin{tabular}{|c|c|c|c|c|c|}
\hline Amino Acid & Defatted STDM & ATH & NTH & Fr.A3 & Fr.B2 \\
\hline Asp (D) & 98.2 & 96.9 & 97.3 & 79.9 & 91.2 \\
\hline Glu (E) & 127.6 & 125.2 & 125.7 & 94.0 & 106.9 \\
\hline Ser $(S)$ & 71.4 & 70.5 & 70.8 & 65.2 & 60.8 \\
\hline Gly (G) & 79.6 & 76.8 & 77.3 & 63.8 & 69.6 \\
\hline His $(\mathrm{H})$ & 75.4 & 74.7 & 74.6 & 81.1 & 73.9 \\
\hline $\operatorname{Arg}(\mathrm{R})$ & 69.7 & 70.2 & 68.9 & 53.6 & 61.9 \\
\hline $\operatorname{Thr}(\mathrm{T})$ & 48.5 & 47.7 & 48.3 & 36.5 & 41.2 \\
\hline Cys (C) & 3.9 & 4.1 & 4.5 & 6.4 & 5.5 \\
\hline $\operatorname{Tyr}(Y)$ & 11.3 & 11.7 & 12.6 & 24.0 & 22.5 \\
\hline Lys (K) & 29.6 & 30.2 & 29.5 & 25.6 & 29.1 \\
\hline $\operatorname{Ala}(\mathrm{A})$ & 79.4 & 80.1 & 80.5 & 89.8 & 86.1 \\
\hline Pro (P) & 9.7 & 9.4 & 9.2 & 14.9 & 10.6 \\
\hline Val (V) & 72.4 & 73.6 & 73.1 & 85.4 & 81.7 \\
\hline $\operatorname{Met}(\mathrm{M})$ & 24.7 & 25.6 & 25.3 & 21.2 & 20.0 \\
\hline Ile (I) & 53.9 & 54.7 & 53.4 & 78.7 & 70.1 \\
\hline Leu (L) & 94.3 & 96.3 & 97.1 & 103.9 & 92.5 \\
\hline $\operatorname{Trp}(\mathrm{W})$ & 10.8 & 12.4 & 11.6 & 26.4 & 21.9 \\
\hline Phe (F) & 39.6 & 39.9 & 40.3 & 49.6 & 54.5 \\
\hline Total & 1000 & 1000 & 1000 & 1000.0 & 1000.0 \\
\hline Aromatic amino acids & 137.1 & 138.7 & 139.1 & 181.1 & 172.8 \\
\hline Hydrophobic amino acids & 384.8 & 392 & 390.5 & 469.9 & 437.4 \\
\hline
\end{tabular}

\subsubsection{Peptide Profiles and Compositions of Fr.A3 and Fr.B2}

In addition to the amino acid composition, peptide size and sequence are two other key factors that affect the activity of protein hydrolysates and peptides [8]. As shown in Table 1, the amino acid compositions of ATH and NTH were similar, but the radical scavenging activity of ATH was higher than that of NTH. Therefore, to further explain the difference in the activities of Fr.A3 and Fr.B2, their peptide profiles were obtained using reversed-phase high performance liquid chromatography (RP-HPLC) (Figure 3). Partial peptides in the two fractions were prepared, and their amino acid sequences were determined using a Procise Protein/Peptide Sequencer and Electrospray ionization mass spectrometry 
(ESI-MS) (Table 4). The activities of the peptides were evaluated based on their antioxidant scores, which are based on the presence and position of certain amino acid residues in the peptide sequences [32].
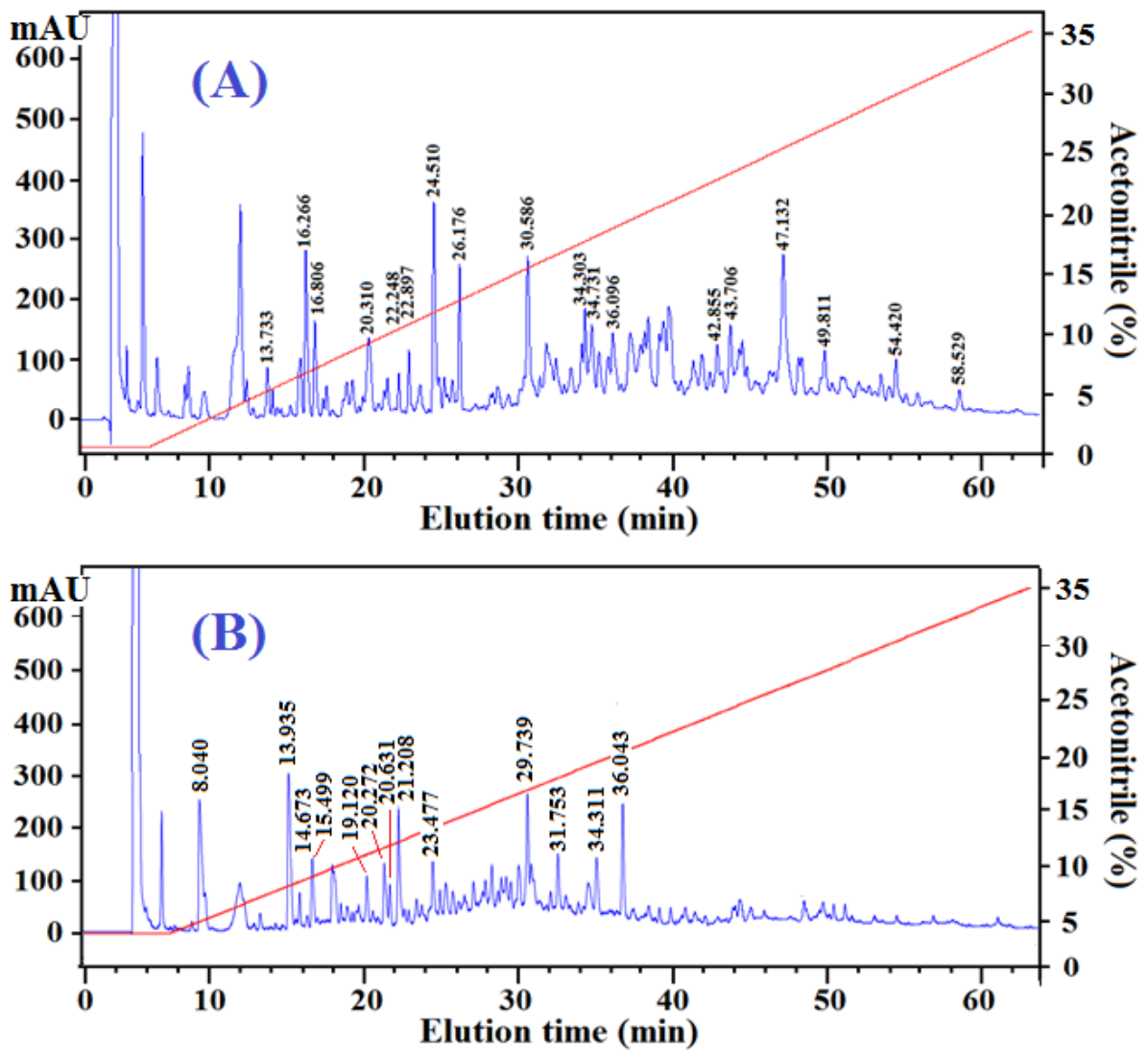

Figure 3. Elution profiles of Fr.A3 (A) and Fr.B2 (B) obtained by RP-HPLC on a Zorbax SB-C18 column $(4.6 \mathrm{~mm} \times 250 \mathrm{~mm}$, Agilent, USA). Absorbance was measured at $220 \mathrm{~nm}$.

As shown in Figure 3, there are two distinct differences in the HPLC chromatograms of Fr.A3 and Fr.B2. Fr.A3 was composed of more peptides, and the components were primarily eluted between 10 and $60 \mathrm{~min}$, whereas Fr.B2 had fewer peptides and was primarily eluted between 10 and $40 \mathrm{~min}$. RP-HPLC utilizes a non-polar stationary phase and a moderately polar, aqueous mobile phase. With the stationary phase, the retention time is longer for molecules that are more non-polar, whereas polar molecules elute more readily. Therefore, based on their shorter retention time, the hydrophobic properties of the peptides in the Fr.B2 might be weaker than those of Fr.A3. This finding agreed with previous results indicating that the hydrophobic amino acid content of Fr.A3 was higher than that of Fr.B2 (Table 3).

Using RP-HPLC, 18 peptides from Fr.A3 and 13 peptides from Fr.B2 were prepared, and their amino acid sequences were determined (Table 4). The 18 peptides from Fr.A3 included five tripeptides, six tetrapeptides, six pentapeptides, and one hexapeptide, and the mean molecular weight was $524.78 \mathrm{kDa}$ based on their theoretical MWs. The 13 peptides from Fr.B2 included three tetrapeptides, nine pentapeptides and one decapeptide, and the mean molecular weight was $585.91 \mathrm{kDa}$. These results indicated that the peptides from Fr.A3 had smaller molecular sizes and lower MWs. 
Table 4. Potential antioxidant peptides and their antioxidant scores from Fr.A3 and Fr.B2, as identified by Procise Protein/Peptide Sequencer and ESI-MS.

\begin{tabular}{|c|c|c|c|c|c|}
\hline No. & $\begin{array}{c}\text { Retention } \\
\text { Time (min) }\end{array}$ & $\begin{array}{c}\text { Observed } \\
\text { Mass (Da) } \\
\end{array}$ & $\begin{array}{l}\text { Calculated } \\
\text { Mass (Da) }\end{array}$ & $\begin{array}{l}\text { Amino Acid } \\
\text { Sequence }\end{array}$ & Antioxidant Score \\
\hline \multicolumn{6}{|c|}{ Peptides from Fr.A3 } \\
\hline A01 & 13.733 & 335.33 & 335.36 & YGP & 5.5 \\
\hline A02 & 16.266 & 482.42 & 482.44 & YEGD & 4.5 \\
\hline A03 & 16.806 & 463.53 & 463.55 & QWM & 7.5 \\
\hline A04 & 20.310 & 538.50 & 538.51 & EYNN & 4 \\
\hline A05 & 22.248 & 423.41 & 423.42 & QNY & 4.5 \\
\hline A06 & 22.897 & 331.30 & 331.33 & QAGG & 2 \\
\hline A07 & 24.510 & 429.45 & 429.47 & QPW & 8.5 \\
\hline A08 & 26.176 & 407.41 & 407.42 & QFN & 3 \\
\hline A09 & 30.586 & 660.69 & 660.72 & DVIEW & 9.5 \\
\hline A10 & 34.303 & 902.91 & 902.9 & QYDEYW & 9.5 \\
\hline A11 & 34.731 & 574.64 & 574.67 & WVGTI & 9.5 \\
\hline A12 & 36.096 & 563.57 & 563.60 & DLYPG & 5 \\
\hline A13 & 42.855 & 571.61 & 571.62 & YVAGY & 6 \\
\hline A14 & 43.706 & 489.49 & 489.52 & DVWA & 8 \\
\hline A15 & 47.132 & 528.58 & 528.60 & QPVW & 9.5 \\
\hline A16 & 49.811 & 681.73 & 681.74 & QELHR & 3 \\
\hline A17 & 54.420 & 619.69 & 619.71 & EYIPV & 7.5 \\
\hline A18 & 58.529 & 441.45 & 441.48 & QPPT & 3 \\
\hline \multicolumn{6}{|c|}{ Peptides from Fr.B2 } \\
\hline B01 & 8.040 & 446.39 & 446.41 & QGGEG & 2 \\
\hline B02 & 13.935 & 538.48 & 538.51 & YENGG & 4.5 \\
\hline B03 & 14.673 & 506.44 & 506.46 & QESGS & 2 \\
\hline B04 & 15.499 & 510.46 & 510.50 & QYSGG & 4 \\
\hline B05 & 19.120 & 521.49 & 521.52 & EGYPG & 4 \\
\hline B06 & 20.272 & 407.40 & 407.42 & QFGG & 3 \\
\hline B07 & 20.631 & 494.48 & 494.50 & QFGGS & 3 \\
\hline B08 & 21.208 & 464.45 & 464.47 & QFGGG & 3 \\
\hline B09 & 23.477 & 681.73 & 681.74 & WGYAW & 10 \\
\hline B10 & 29.739 & 742.83 & 742.86 & YIVYW & 12 \\
\hline B11 & 31.753 & 1214.21 & 1214.24 & WGDAGGYYYY & 10 \\
\hline B12 & 34.311 & 544.62 & 544.64 & QILTA & 3 \\
\hline B13 & 36.043 & 543.54 & 543.57 & QPWN & 8 \\
\hline
\end{tabular}

2.4. Protective Effects of Fr.A3 and Fr.B2 on Lipid Peroxidation in a Linoleic Acid System.

In the radical scavenging experiments, Fr.A3 and Fr.B2 showed strong DPPH $\bullet$, HO $\bullet$, and $\mathrm{O}_{2}^{-} \bullet$ scavenging activities. However, antioxidants have different mechanisms of action (i.e., radical chain inhibition, metal chelation, oxidative enzyme inhibition or antioxidant enzyme cofactors). Therefore, the radical scavenging assay does not reflect the multiple mechanisms through which the samples may act as antioxidants to retard and/or inhibit lipid oxidation in a food system. In this section, the abilities of Fr.A3 and Fr.B2 to suppress lipid peroxidation in a linoleic acid system were investigated. 
As shown in Figure 4, the control (without antioxidant) had the highest experimental absorbance value, indicating the highest degree of oxidation among the samples after a seven-day incubation period. Fr.A3, Fr.B2 and glutathione, however, effectively inhibited lipid peroxidation in the linoleic acid emulsion system for the entire seven days. From days 1-3, the inhibition activity of Fr.A3 was close to that of glutathione for lipid peroxidation in the test system, but the inhibition ability of Fr.A3 was stronger than that of glutathione from days 3-7. From days 1-4, Fr.B2 exhibited weaker inhibition activity than glutathione, but the inhibition activity of Fr.B2 was higher than that of glutathione from days 4-7. Over the entire testing period, Fr.B2 was less effective at inhibiting linoleic acid oxidation compared with Fr.A3.

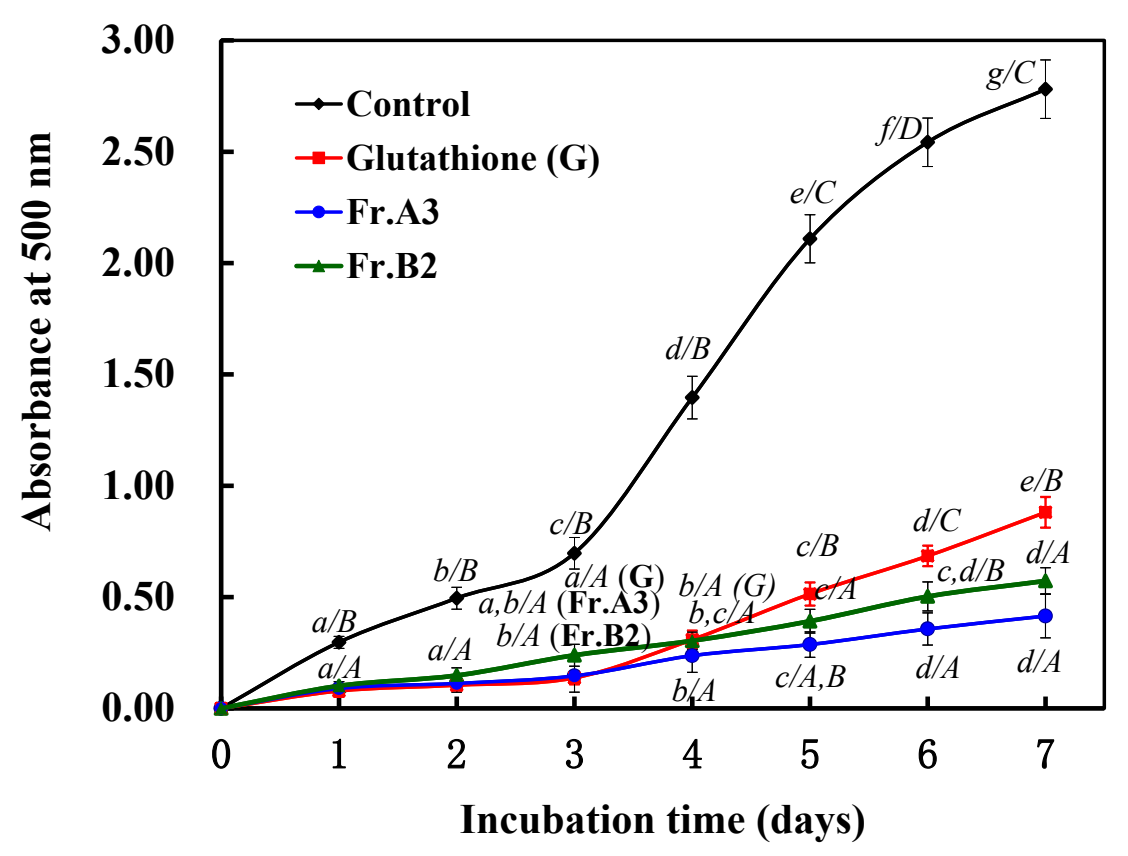

Figure 4. Lipid peroxidation inhibition assays of Fr.A3 and Fr.B2 in a linoleic acid oxidation system over seven days. The degree of linoleic acid oxidation was assessed by measuring the optical density at $500 \mathrm{~nm}$ at $24-\mathrm{h}$ intervals. Glutathione was used as the positive control.

\section{Discussion}

Bioactive peptides with 2-20 amino acids that are derived from food sources have received increased attention due to their more certain and efficient effects in the prevention or control of human diseases. Antioxidant peptides have received increased attention due to their significant role in the prevention and treatment of different disorders, such as atherosclerosis, cancer, diabetes mellitus, and coronary heart diseases $[41,42]$. Fish proteins have long been recognized for their nutritional and functional properties, the latter of which can be modified by physical, chemical or enzymatic treatments. Recently, research has focused on the liberation of bioactive peptides derived from fish proteins using enzyme technology, which involves milder processing conditions, relatively simpler reaction controls, and minimal byproduct formation [12,13]. Furthermore, the resulting peptides are intended for use as functional food ingredients to help maintain human health. However, the protein source, DH, amino acid composition, MWs, peptides sequences, and peptide compositions of the protein 
hydrolysates determine their bioactivities and functional properties [43]. At present, many studies have been performed on the antioxidant abilities of hydrolysates or bioactive peptides from seafood sources, including croceine croaker (Pseudosciaena crocea) muscles [4], sea urchin gonads [44], tilapia (Oreochromis niloticus) gelatin [6], monkfish (Lophius litulon) [13], Amur sturgeon skin [45], thornback ray [46], and bluefin leatherjacket (Navodon septentrionalis) heads [47].

In this experiment, five proteases were used to hydrolyze defatted STDM. ATH and NTH showed higher antioxidant activities than the other hydrolysates did. The results indicated that the antioxidant activities of the STDM protein hydrolysates were affected by the type of the enzyme used, which agrees with the report that the type of protease applied in hydrolysis is crucial to hydrolysate activity because of the different peptide bond cleavage patterns involved [18]. Moreover, the radical scavenging activities of the hydrolysates were positively correlated with the DH (\%). The data suggested that the peptides in the different hydrolysates, which might have different chain lengths and amino acid sequences, contributed to radical scavenging to varying degrees. Therefore, ATH and NTH were most likely composed of more active peptides than the other hydrolysates did. These active peptides are electron donors that react with free radicals to convert them to more stable products and terminate the radical chain reaction. However, defatted STDM, ATH and NTH showed similar amino acid profiles, but their radical scavenging activities were different. These results indicated that the hydrolysis process did not significantly alter the profile of the amino acids $[32,48]$ and that the differences in the activities may be caused by other factors, such as molecular size and amino acid sequences. Due to their free radical scavenging activities, ATH and NTH were further used for the preparation of the antioxidant peptides fractions.

Protein hydrolysates are composed of free amino acids and short-chain peptides that exhibit numerous advantages as nutraceuticals, functional foods or medicines. In fact, peptides and protein hydrolysates display different antioxidant activities depending on the peptide size, the amino acid sequence, and the presence of amino acids involved in oxidative reactions [13,49,50]. Therefore, high antioxidant peptides fractions (Fr.A3 and Fr.B2) were prepared using ultrafiltration and conventional chromatographic methods. Their amino acid compositions and peptide profiles were analyzed to determine the differences in their antioxidant activities. The results showed that Fr.A3 and Fr.B2 exhibited higher antioxidant effects than their original hydrolysates. Table 3 indicated that the amino acid compositions of Fr.A3 and Fr.B2 were different from those of the defatted STDM and its hydrolysates. The hydrophobic and aromatic amino acid contents of these fractions were significantly higher than those of ATH and NTH. Pownall et al. confirmed that the higher contents of hydrophobic and aromatic amino acids facilitated the radical scavenging and metal chelating activities of protein hydrolysate fractions from pea seeds (P. sativum L.) [38]. Himaya et al. reported that hydrophobic amino acids facilitated interactions with hydrophobic targets, such as the cell membrane, and thereby enhanced the bioavailability [2]. Additionally, hydrophobic peptides can protect against macromolecular oxidation by donating photons to reactive radicals. Mendis et al. reported that the high potency of HGPLGPL as an antioxidant could be derived from the hydrophobic amino acids, which may facilitate greater interactions between the peptide and fatty acids [13]. Furthermore, aromatic amino acids increased the antioxidant activities of peptides and protein hydrolysates because they easily donated protons to electron-deficient radicals, maintained their stabilities via resonance structures, and enhanced their radical scavenging activities [8,38-40]. Therefore, the high hydrophobic and aromatic 
amino acid contents of Fr.A3 and Fr.B2 might be important for their high antioxidant activities. Lipid peroxidation is a complex process involving the formation and propagation of lipid radicals and hydroperoxides in the presence of oxygen [51]. The strong lipid peroxidation inhibition activity of Fr.A3 in a linoleic acid system suggested that Fr.A3 could react with radicals in the system, including peroxyl radicals, and thereby inhibit the propagation cycle of lipid peroxidation. The amino acid profile of Fr.A3 (Table 3) indicated that Fr.A3 was rich in hydrophobic amino acids, which might lead to greater interactions between the peptides and the fatty acids. Moreover, histidine-containing peptides are active against lipid peroxidation because of an imidazole moiety, which may be involved in hydrogen donation for lipid radical trapping [40,52]. Therefore, we speculated that the hydrophobic amino acids and the His residues might simultaneously contribute to the higher antioxidant activity of Fr.A3.

Molecular weight is typically understood to be a key factor affecting the activities of peptides. Table 4 showed that the mean molecular weights of Fr.A3 and Fr.B2 were $524.78 \mathrm{kDa}$ and $585.91 \mathrm{kDa}$ based on their theoretical MWs, respectively. These results indicated that the peptides from Fr.A3 had smaller molecular sizes and lower MWs. These findings are consistent with a report stating that smaller antioxidants have a greater probability of engaging in more effective interactions with free radicals and inhibiting the propagation of lipid peroxidation. Additionally, they have a greater chance of crossing the intestinal barrier to exert biologically relevant functions. Using the method developed by Conway et al. [53], the antioxidant scores of the 31 peptides were calculated and shown in Table 4. Of the 18 peptide sequences from Fr.A3, 14 peptides contained one or more W and/or Y residues, which accounts for their high antioxidant scores. Furthermore, 10 peptides possessed a terminal $\mathrm{W}$ and/or Y residue, four peptides had a terminal $\mathrm{P}, \mathrm{M}$, I or $\mathrm{V}$ residue, and 12 peptides contained one or more H, K, P, F, V and/or I residues, which are also considered beneficial to the antioxidant activities of the peptides. Due to these particular amino acid residues in the sequences, the mean antioxidant score of the 18 peptides was 6.11 . For the 13 peptide sequences from Fr.B2, seven contained one or more $\mathrm{W}$ and/or $\mathrm{Y}$ residues, four possessed a terminal $\mathrm{W}$ and/or $\mathrm{Y}$ residue, and seven peptides had one or more $\mathrm{H}, \mathrm{K}, \mathrm{P}, \mathrm{F}, \mathrm{V}$ and/or I residues, but no peptide had an $\mathrm{N}$-terminal $\mathrm{V}$ or $\mathrm{L}$ residue or a C-terminal $\mathrm{M}$ residue. The mean antioxidant score of the 13 peptides from Fr.B2 was 5.27, which was lower than that of the 18 peptides from Fr.A3. This result was consistent with the data in Table 2, which indicated that Fr.A3 exhibited stronger radical (DPPH•, $\mathrm{HO} \bullet$, and $\mathrm{O}_{2}^{-} \bullet$ ) scavenging activities than Fr.B2 did. Moreover, these mean antioxidant scores also substantiated the data in Table 3 and the previous discussion, indicating that both amino acid composition and position in peptide sequences are important factors for the antioxidant activities of peptides.

\section{Experimental Section}

\subsection{Materials}

Skipjack tuna dark muscle (K. pelamis) (STDM) was provided by Zhejiang Hailisheng Group Co., Ltd. (Zhejiang, China). Trypsin, pepsin, papain, glutathione, trifluoroacetic acid (TFA), 1,1-diphenyl2-picrylhydrazyl (DPPH), Sephadex G-25, and trinitrobenzene sulfonic acid (TNBS) were purchased from Sigma-Aldrich Trading Co., Ltd. (Shanghai, China). Alcalase and Neutrase were purchased from 
Novozymes Biotechnology Co., Ltd. (Tianjin, China). Acetonitrile (ACN) was purchased from Thermo Fisher Scientific Co., Ltd. (Shanghai, China). All other chemicals and reagents were of analytical grade and were obtained from Sinopharm Chemical Reagent Co., Ltd. (Shanghai, China).

\subsection{Preparation of Protein Hydrolysates of STDM}

The STDM was rinsed using tap water, pounded into a homogenate, and defatted as previously described [7]. The homogenate and isopropanol were mixed in a ratio of 1:4 (w/v) and stirred continuously for $4 \mathrm{~h}$ at $35{ }^{\circ} \mathrm{C}$. Isopropanol was replaced every $2 \mathrm{~h}$. The precipitate was collected by centrifugation at $9000 \mathrm{rpm}$ for $15 \mathrm{~min}$ at $4{ }^{\circ} \mathrm{C}$, freeze-dried and stored at $-20{ }^{\circ} \mathrm{C}$.

The defatted STDM was dissolved $(10 \% \mathrm{w} / \mathrm{v})$ in different buffer solutions and hydrolyzed for $4 \mathrm{~h}$ using each of the five proteases (listed below) at their optimal temperatures and $\mathrm{pH}$ conditions with an enzyme/substrate $(\mathrm{E} / \mathrm{S})$ ratio of $2 \%(\mathrm{w} / \mathrm{w})$. The optimal conditions were as follows: trypsin $(0.05 \mathrm{M}$ Tris-HCl, $\left.\mathrm{pH} 8.0,37^{\circ} \mathrm{C}\right)$, pepsin $\left(0.05 \mathrm{M}\right.$ Gly-HCl, $\left.\mathrm{pH} 2.0,37^{\circ} \mathrm{C}\right)$, papain $(0.05 \mathrm{M}$ phosphate, $\mathrm{pH} 6.5$, $\left.50{ }^{\circ} \mathrm{C}\right)$, Alcalase $\left(0.05 \mathrm{M}\right.$ Gly- $\left.\mathrm{NaOH}, \mathrm{pH} 9.5,50{ }^{\circ} \mathrm{C}\right)$ and Neutrase $\left(0.05 \mathrm{M}\right.$ phosphate, $\left.\mathrm{pH} 7.0,60^{\circ} \mathrm{C}\right)$. Enzymatic hydrolysis was terminated by heating for $10 \mathrm{~min}$ in boiling water, and the hydrolysates were centrifuged at 10,000 rpm for $15 \mathrm{~min}$. The resulting supernatants were freeze-dried and stored at $-20{ }^{\circ} \mathrm{C}$ until further analysis. The protein hydrolysates prepared using Alcalase and Neutrase were called ATH and NTH, respectively.

\subsection{Determination of the Degree of Hydrolysis $(D H)$}

The $\mathrm{DH}$, defined as the percentage ratio of the number of peptide bonds broken to the total number of bonds per unit weight, was calculated according to a previously described method [54]. Hydrolysate $(50 \mu \mathrm{L})$ was mixed with $0.5 \mathrm{~mL}$ of phosphate buffer $(0.2 \mathrm{M}, \mathrm{pH} 8.2)$ and $0.5 \mathrm{~mL}$ of TNBS reagent $(0.05 \%)$ freshly prepared by diluting with deionized water. After being incubated at $50{ }^{\circ} \mathrm{C}$ for $1 \mathrm{~h}$ in a water bath, the reaction in mixture was stopped by adding $1 \mathrm{~mL}$ of $\mathrm{HCl}(0.1 \mathrm{M})$ and incubated at $25{ }^{\circ} \mathrm{C}$ for $30 \mathrm{~min}$. The absorbance was measured at $420 \mathrm{~nm}$. L-Leucine was used as a standard. To determine the total amino acid content, defatted skate muscle was completely hydrolyzed with $6 \mathrm{M} \mathrm{HCl}$ with a sample/acid ratio of $1: 100$ at $120^{\circ} \mathrm{C}$ for $24 \mathrm{~h}$. $\mathrm{DH}(\%)$ was calculated using the following equation:

$$
\mathrm{DH}=\left[\left(\mathrm{A}_{\mathrm{t}}-\mathrm{A}_{0}\right) /\left(\mathrm{A}_{\max }-\mathrm{A}_{0}\right)\right] \times 100 \%
$$

where, $A_{t}$ is the number of $\alpha$-amino acids released at time $t, A_{0}$ is the number of $\alpha$-amino acids in the supernatant at $0 \mathrm{~h}$, and $A_{\max }$ is the total number of $\alpha$-amino acids obtained after acid hydrolysis at $120{ }^{\circ} \mathrm{C}$ for $24 \mathrm{~h}$.

\subsection{Determination of Amino Acid Composition}

The amino acid composition of samples was determined according to the method of Siswoyo et al. with slight modifications [52]. To determine the amino acid composition, freeze-dried collagen was dissolved in distilled water to obtain a concentration of $1 \mathrm{mg} / \mathrm{mL}$, and an aliquot of $50 \mathrm{~mL}$ was dried and hydrolyzed in vacuum-sealed glass tube at $110{ }^{\circ} \mathrm{C}$ for $24 \mathrm{~h}$ in the presence of $6 \mathrm{M} \mathrm{HCl}$, which contained $0.1 \%$ phenol. Norleucine (Sigma Aldrich, Inc., St. Louis, MO, USA) was used as an internal standard. After hydrolysis, the samples were again vacuum-dried, dissolved in application buffer and 
injected into an automated amino acid analyzer (HITACHI 835-50 Amino Acid Analyzer, Japan). The determinations were performed in triplicate, and the data corresponded to the mean values. The standard deviations were lower than $2 \%$ in all cases.

\subsection{Antioxidant Activities}

\subsubsection{Radical (DPPH•, $\mathrm{HO} \bullet$, and $\mathrm{O}_{2}^{-} \bullet$ ) Scavenging Assays}

The radical ( $\mathrm{DPPH} \bullet, \mathrm{HO} \bullet$, and $\mathrm{O}_{2}^{-} \bullet$ ) scavenging assays were performed as described by Wang et al. with ascorbic acid (AA) as positive control [3]. The results were expressed as the median effective concentration $\left(\mathrm{EC}_{50}\right)$, which was defined as the concentration at which a sample caused a $50 \%$ decrease in the initial concentrations of $\mathrm{DPPH} \bullet, \mathrm{HO} \bullet$, and $\mathrm{O}_{2}^{-} \bullet$

\section{$\mathrm{HO} \cdot$ Scavenging Activity}

HO- scavenging activity was measured using the method developed by Wang et al. [3]. In this system, $\mathrm{HO} \bullet$ is generated by the Fenton reaction. $\mathrm{HO} \cdot$ can oxidize $\mathrm{Fe}^{2+}$ to $\mathrm{Fe}^{3+}$, and only $\mathrm{Fe}^{2+}$ can combine with 1,10-phenanthroline to form a red compound $\left(1,10\right.$-phenanthroline-Fe $\left.{ }^{2+}\right)$. It shows maximum absorbance at $536 \mathrm{~nm}$. The concentration of $\mathrm{HO} \bullet$ is reflected by the degree of decolorization of the reaction solution. Briefly, 1,10-phenanthroline solution $(1.0 \mathrm{~mL}, 1.865 \mathrm{mM})$ and the sample $(2.0 \mathrm{~mL})$ were added into a screw-capped tube and mixed. The $\mathrm{FeSO}_{4} \cdot 7 \mathrm{H}_{2} \mathrm{O}$ solution $(1.0 \mathrm{~mL}$, $1.865 \mathrm{mM}$ ) was then pipetted into the mixture. The reaction was initiated by adding $1.0 \mathrm{~mL} \mathrm{H}_{2} \mathrm{O}_{2}$ $(0.03 \% \mathrm{v} / \mathrm{v})$. After incubation at $37{ }^{\circ} \mathrm{C}$ for $60 \mathrm{~min}$ in a water bath, the absorbance of the reaction mixture was measured at $536 \mathrm{~nm}$ against a reagent blank. Reaction mixture without any antioxidant served as the negative control, and mixture without $\mathrm{H}_{2} \mathrm{O}_{2}$ served as the blank. $\mathrm{HO} \bullet$ scavenging activity (HRSA) was calculated by the following formula:

$$
\operatorname{HRSA}(\%)=\left[\left(\mathrm{A}_{\mathrm{s}}-\mathrm{Ac}_{\mathrm{c}}\right) /\left(\mathrm{A}_{\mathrm{b}}-\mathrm{A}_{\mathrm{c}}\right)\right] \times 100 \%
$$

where $A_{s}$ is the sample absorbance; $A_{c}$ is the control group absorbance; and $A_{b}$ is the blank absorbance.

\section{$\mathrm{DPPH} \bullet$ Scavenging Activity}

DPPH• scavenging activity was tested as previously described [3]. Two milliliters of deionized water containing different concentrations of sample (from $0.125-2.0 \mathrm{mg} / \mathrm{mL}$ ) were placed in the cuvettes, and then $500 \mu \mathrm{L}$ of ethanol solution of DPPH $(0.02 \%)$ and $1.0 \mathrm{~mL}$ of ethanol were added. The control containing DPPH solution without sample was also prepared. In blank, DPPH solution was replaced with ethanol. The antioxidant activity of the sample was evaluated using the relative amount of inhibition of $\mathrm{DPPH} \bullet$ with the following equation:

$$
\mathrm{DPPH} \bullet \text { scavenging activity }(\%)=\left(\mathrm{A}_{\mathrm{c}}+\mathrm{A}_{\mathrm{b}}-\mathrm{As}\right) / \mathrm{A}_{\mathrm{c}} \times 100 \%
$$

where $\mathrm{A}_{\mathrm{s}}$ is the sample absorbance; $\mathrm{A}_{\mathrm{c}}$ is the control group absorbance; and $\mathrm{A}_{\mathrm{b}}$ is the blank absorbance. 
$\mathrm{O}_{2}^{-} \cdot$ Scavenging Activity

The $\mathrm{O}_{2}^{-}$scavenging activity of the sample was investigated by the previous method [3]. In the experiment, $\mathrm{O}_{2}^{-} \bullet$ was generated in $1 \mathrm{~mL}$ of nitrotetrazolium blue chloride $(2.52 \mathrm{mM}), 1 \mathrm{~mL}$ of NADH $(624 \mathrm{mM}$ ), and $1 \mathrm{~mL}$ of different concentrations of samples (from $0.065-1.0 \mathrm{mg} / \mathrm{mL}$ ). The reaction was initiated by adding $1 \mathrm{~mL}$ of phenazine methosulfate solution $(120 \mu \mathrm{g} / \mathrm{mL})$ to the reaction mixture. The absorbance was measured at $560 \mathrm{~nm}$ against the corresponding blank after 5 min incubation at $25{ }^{\circ} \mathrm{C}$. The capacity of scavenging $\mathrm{O}_{2}^{-} \bullet$ was calculated using the following equation:

$$
\mathrm{O}_{2}^{-} \bullet \text { scavenging activity }(\%)=\left[\left(\mathrm{A}_{\mathrm{c}}-\mathrm{A}_{\mathrm{s}}\right) / \mathrm{A}_{\mathrm{c}}\right] \times 100 \%
$$

where $\mathrm{A}_{\mathrm{s}}$ is the absorbance with sample; and $\mathrm{A}_{\mathrm{c}}$ is the absorbance without sample.

\subsubsection{Lipid Peroxidation Inhibition Assay}

The protective effect of the isolated peptides on lipid peroxidation in a linoleic acid model system was measured based on a previously described method [55]. Briefly, a sample $(0.5 \mathrm{mg} / \mathrm{mL})$ dissolved in $10 \mathrm{~mL}$ of phosphate buffer $(0.05 \mathrm{M}, \mathrm{pH} 7.0)$ was added to $10 \mathrm{~mL}$ of $99.5 \%$ ethanol containing $0.13 \mathrm{~mL}$ of linoleic acid, and the final volume was adjusted to $25 \mathrm{~mL}$ with distilled water. The mixture, stored in a sealed screw-cap conical tube, was incubated at $40{ }^{\circ} \mathrm{C}$ in the dark. The degree of linoleic acid oxidation was measured at 24-h intervals for seven days using the ferric thiocyanate method, in which $0.1 \mathrm{~mL}$ of the reaction mixture was mixed with $4.7 \mathrm{~mL}$ of ethanol $(75 \%), 0.1 \mathrm{~mL}$ of ammonium thiocyanate $(30 \%)$, and $0.1 \mathrm{~mL}$ of ferrous chloride $(0.02 \mathrm{M})$ in $3.5 \% \mathrm{HCl}$. After $3 \mathrm{~min}$, the degree of color development, which was indicative of linoleic acid oxidation, was measured at $500 \mathrm{~nm}$.

\subsubsection{Antioxidant Score}

For subsequent identification of potentially antioxidant buttermilk protein derived peptides, antioxidant score was established for scoring peptide sequences based on the presence and position of certain amino acid residues. The antioxidant score was calculated according to the method described by Conway et al:: Trp (W) within the amino acid sequence, 5 points; Tyr (Y) within the amino acid sequence, 2 points; short sequence length (2-10 residues), 2 points; His $(H)$, Lys (K), Pro (P), Phe (F), Val (V), or Ile (I) within the sequence, 1 point; Tyr (Y), Trp (W), Val (V), or Leu (L) residues at N-terminus, 0.5 point; and $\operatorname{Trp}(\mathrm{W}), \operatorname{Tyr}(\mathrm{Y})$, and $\operatorname{Met}(\mathrm{M})$ residues at C-terminus, 0.5 point [53].

\subsection{Separation of Antioxidant Peptides}

\subsubsection{Ultrafiltration}

Ultrafiltration is a technique for separating molecules in solution based on molecular size. It is widely used to concentrate target fractions from protein hydrolysates on a MWCO membrane. ATH and NTH were fractionated at $4{ }^{\circ} \mathrm{C}$ by ultrafiltration (8400, Millipore, Hangzhou, China) with $3 \mathrm{kDa}$ molecular weight cutoff (MWCO) membranes (Millipore, Hangzhou, China), appropriate for the laboratory scale. The peptide fractions (ATH-I and ATH-II, NTH-I and NTH-II) were collected and lyophilized for separation in the following step. 


\subsubsection{Gel Filtration Chromatography}

Gel filtration, an effective method for separating bioactive substances with different molecular dimensions, was used for the group separation of the protein hydrolysates. In this study, the ATH-II and NTH-II solutions ( $5 \mathrm{~mL}, 20.0 \mathrm{mg} / \mathrm{mL}$ ) were separately loaded onto a Sephadex G-25 column $(2.6 \times 80 \mathrm{~cm})$ pre-equilibrated with deionized water and eluted at a flow rate of $1 \mathrm{~mL} / \mathrm{min}$. Each eluted fraction $(3 \mathrm{~mL})$ was collected and monitored at $220 \mathrm{~nm}$. Four subfractions (Fr.A1, Fr.A2, Fr.A3 and Fr.A4) from ATH-II and three fractions (Fr.B1, Fr.B2, and Fr.B3) from NTH-II were collected and lyophilized for further studies.

\subsubsection{Reversed-Phase High Performance Liquid Chromatography (RP-HPLC)}

The fractions (Fr.A3 and Fr.B2) with high radical scavenging activities obtained from the Sephadex G-25 column were further separated by RP-HPLC (Agilent 1260 HPLC, Agilent Ltd., Santa Clara, CA, USA). The Fr.A3 and Fr.B2 solutions $(20 \mu \mathrm{L}, 100.0 \mu \mathrm{g} / \mathrm{mL})$ were injected separately into a Zorbax SB-C18 column $(4.6 \mathrm{~mm} \times 250 \mathrm{~mm}$, Agilent, USA) using a linear gradient of ACN $(0 \%-0 \%$ for $6 \mathrm{~min}$ and $0 \%-100 \%$ over $100 \mathrm{~min})$ at a flow rate of $1.0 \mathrm{~mL} / \mathrm{min}$. The elution peaks were monitored at $220 \mathrm{~nm}$, and the fractions were collected manually, lyophilized and stored until further analysis.

\subsection{Identification of the Peptide Sequences and Molecular Masses}

The antioxidant peptides of SP-A and SP-B were subjected to N-terminal amino acid sequencing on an Applied Biosystems 494 protein sequencer (Perkin Elmer Wallace Inc., Akron, OH, USA) according to previous methods [3]. Edman degradation was performed according to the standard program supplied by Applied Biosystems.

Accurate molecular masses of SP-A and SP-B were determined using a Q-TOF mass spectrometer (Micromass, Waters, Los Angeles, California, USA) coupled with an electrospray ionization (ESI) source based on a previous method developed by Luo et al. [16]. Ionization was performed in positive mode with a capillary voltage of $3500 \mathrm{~V}$. Nitrogen was maintained at 40 psi for nebulization and $9 \mathrm{~L} / \mathrm{min}$ at $350{ }^{\circ} \mathrm{C}$ for evaporation temperature. The data were collected in centroid mode from $\mathrm{m} / \mathrm{z}$ 100-2000.

\subsection{Statistical Analysis}

All experiments were conducted in triplicate $(n=3)$, and the values were expressed as mean \pm standard deviation (SD). An ANOVA test using the SPSS 19.0 software was performed to analyze the experimental data. Duncan's multiple range test $(p<0.05)$ was used to measure the significant differences between the means of the parameters.

\section{Conclusions}

In this study, dark muscle from skipjack tuna (K. pelamis) was hydrolyzed using five separate proteases, including pepsin, trypsin, Neutrase, papain and Alcalase. Two hydrolysates, ATH and NTH, 
prepared using Alcalase and Neutrase, respectively, showed the strongest radical scavenging activities. Using ultrafiltration and gel filtration chromatography, two fractions, Fr.A3 and Fr.B2, were prepared from ATH and NTH, respectively, and their antioxidant activities, amino acid compositions and peptide profiles were investigated. The results indicated that Fr.A3 and Fr.B2 could effectively inhibit lipid peroxidation in the linoleic acid model system and scavenge $\mathrm{DPPH} \bullet$, $\mathrm{HO} \bullet$, and $\mathrm{O}_{2}^{-} \bullet$. Smaller molecular sizes, hydrophobic and aromatic amino acid residues, and amino acid sequences were the key factors determining the antioxidant activities of the proteins, hydrolysates and peptides. Moreover, the present study provided useful information for increasing the commercial value of STDM byproducts as multifunctional ingredients, and suggested new ways to increase its recognition as a natural source of antioxidants that are capable of preventing oxidation in food systems.

\section{Acknowledgments}

This research was financially supported by the National Natural Science Foundation of China (NSFC) (No. 31471609), the International Science and Technology Cooperation Program of China (No. 2012DFA30600), and the Special Program for the Science and Technology Plan of Zhejiang Province (No. 2009C03017-2), and the Public Projects of Zhejiang Province (2014C33034). The authors are greatly indebted to Sheng-Long Zhao at School of Marine Science and Technology, Zhejiang Ocean University, for his valuable help in identifying the fish material.

\section{Author Contributions}

Conceived and designed the experiments: Chang-Feng Chi, Bin Wang and Hong-Yu Luo. Performed the experiments: Zhong-Rui Li, Fa-Yuan Hu and Bin Wang. Analyzed the data: Zhong-Rui Li, Chang-Feng Chi and Bin Wang. Contributed reagents/materials/analytical tools: Bin Wang and Hong-Yu Luo. Composed the paper: Bin Wang and Chang-Feng Chi.

\section{Conflicts of Interest}

The authors declare no conflict of interest.

\section{References}

1. Farvin, K.H.; Lystbæk Andersen, L.; Hauch Nielsen, H.; Jacobsen, C.; Jakobsen, G.; Johansson I.; Jessena, F. Antioxidant activity of Cod (Gadus morhua) protein hydrolysates: In vitro assays and evaluation in 5\% fish oil-in-water emulsion. Food Chem. 2014, 149, 326-334.

2. Himaya, S.W.; Ryu, B.; Ngo, D.H.; Kim, S.K. Peptide isolated from Japanese flounder skin gelatin protects against cellular oxidative damage. J. Agric. Food Chem. 2012, 60, 9112-9119.

3. Wang, B.; Li, Z.R.; Chi, C.F.; Zhang, Q.H.; Luo, H.Y. Preparation and evaluation of antioxidant peptides from ethanol-soluble proteins hydrolysate of Sphyrna lewini muscle. Peptides 2012, 36, 240-250.

4. Chi, C.F.; Hu, F.Y.; Wang, B.; Ren, X.J.; Deng, S.G.; Wu, C.W. Purification and characterization of three antioxidant peptides from protein hydrolyzate of croceine croaker (Pseudosciaena crocea) muscle. Food Chem. 2015, 168, 662-667. 
5. Memarpoor-Yazdi, M.; Mahaki, H.; Zare-Zardini, H. Antioxidant activity of protein hydrolysates and purified peptides from Zizyphus jujuba fruits. J. Funct. Foods 2014, 10, 144-153.

6. Girgih, A.T.; Udenigwe, C.C.; Hasan, F.M.; Gill, T.A.; Aluko R.E. Antioxidant properties of Salmon (Salmo salar) protein hydrolysate and peptide fractions isolated by reverse-phase HPLC. Food Res. Int. 2013, 52, 315-322.

7. Wang, B.; Li, L.; Chi, C.F.; Ma, J.H.; Luo, H.Y.; Xu, Y.F. Purification and characterisation of a novel antioxidant peptide derived from blue mussel (Mytilus edulis) protein hydrolysate. Food Chem. 2013, 138, 1713-1719.

8. Chang, O.K.; Ha, G.E.; Han, G.S.; Seol, K.H.; Kim, H.W.; Jeong, S.G.; Oh, M.H.; Park, B.Y.; Ham, J.S. Novel antioxidant peptide derived from the ultrafiltrate of ovomucin hydrolysate. J. Agric. Food Chem. 2013, 61, 7294-7300.

9. Hong, J.; Chen, T.T.; Hu, P.; Yang, J.; Wang, S.Y. Purification and characterization of an antioxidant peptide (GSQ) from Chinese leek (Allium tuberosum Rottler) seeds. J. Funct. Foods 2014, 10, 144-153.

10. Nalinanon, S.; Benjakul, S.; Kishimura, H.; Shahidi, F. Functionalities and antioxidant properties of protein hydrolysates from the muscle of ornate threadfin bream treated with pepsin from skipjack tuna. Food Chem. 2011, 124, 1354-1362.

11. Jiang, H.; Tong, T.; Sun, J.; Xu, Y.; Zhao, Z.; Liao, D. Purification and characterization of antioxidative peptides from round scad (Decapterus maruadsi) muscle protein hydrolysate. Food Chem. 2014, 154, 158-163.

12. Nguyen, H.T.M.; Babacar, S.K.S.; Zo, R.; Claire, D.M.; Jacques, M.; Tran, L.T.; Bergé, J.P. Enzymatic hydrolysis of yellowfin tuna (Thunnus albacares) by-products using Protamex protease. Food Technol. Biotech. 2011, 49, 48-55.

13. Mendis, E.; Rajapakse, N.; Kim, S.K. Antioxidant properties of a radical-scavenging peptide purified from enzymatically prepared fish skin gelatin hydrolysate. J. Agric. Food Chem. 2005, $53,581-587$.

14. Najafian, L.; Babji, A.S. Production of bioactive peptides using enzymatic hydrolysis and identification antioxidative peptides from patin (Pangasius sutchi) sarcoplasmic protein hydolysate. J. Funct. Foods 2014, 9, 280-289.

15. Chi, C.F.; Wang, B.; Deng, Y.Y.; Wang, Y.M.; Deng, S.G.; Ma, J.Y. Isolation and characterization of three antioxidant pentapeptides from protein hydrolysate of monkfish (Lophius litulon) muscle. Food Res. Int. 2014, 55, 222-228.

16. Luo, H.Y.; Wang, B.; Li, Z.R.; Chi, C.F.; Zhang, Q.H.; He, G.Y. Preparation and evaluation of antioxidant peptide from papain hydrolysate of Sphyrna lewini muscle protein. LWT-Food Sci. Technol. 2013, 51, 281-288.

17. Ko, J.Y.; Lee, J.H.; Samarakoon, K.; Kim, J.S.; Jeon, Y.J. Purification and determination of two novel antioxidant peptides from flounder fish (Paralichthys olivaceus) using digestive proteases. Food Chem. Toxicol. 2013, 52, 113-120.

18. Ranathunga, S.; Rajapakse, N.; Kim, S.K. Purification and characterization of antioxidative peptide derived from muscle of conger eel (Conger myriaster). Eur. Food Res. Technol. 2006, $222,310-315$. 
19. Intarasirisawat, R.; Benjakul, S, Wu, J.; Visessanguan, W. Isolation of antioxidative and ACE inhibitory peptides from protein hydrolysate of skipjack (Katsuwana pelamis) roe. J. Funct. Foods 2013, 5, 1854-1862.

20. Sun, L.; Zhang, Y.; Zhuang, Y. Antiphotoaging effect and purification of an antioxidant peptide from tilapia (Oreochromis niloticus) gelatin peptides. J. Funct. Foods 2013, 5, 154-162.

21. Sudhakar, S., Nazeer R.A. Structural characterization of an Indian squid antioxidant peptide and its protective effect against cellular reactive oxygen species. J. Funct. Foods 2015, 14, 502-512.

22. Kim, E.K.; Oh, H.J.; Kim, Y.S.; Hwang, J.W.; Ahn, C.B.; Lee, J.S.; Jeon, Y.J.; Moon, S.H.; Sung, S.H.; Jeon, B.T.; Park. P.J. Purification of a novel peptide derived from Mytilus coruscus and in vitro/in vivo evaluation of its bioactive properties. Fish Shellfish Immun. 2013, 34, 1078-1084.

23. Kaewdang, O.; Benjakul, S.; Kaewmanee, T.; Kishimura, H. Characteristics of collagens from the swim bladders of yellowfin tuna (Thunnus albacares). Food Chem. 2014, 155, 264-270.

24. Lee, S.H.; Qian, Z.J.; Kim, S.K. A novel angiotensin I converting enzyme inhibitory peptide from tuna frame protein hydrolysate and its antihypertensive effect in spontaneously hypertensive rats. Food Chem. 2010, 118, 96-102.

25. Hsu, K.C.; Lu, G.H.; Jao, C.L. Antioxidative properties of peptides prepared from tuna cooking juice hydrolysates with orientase (Bacillus subtilis). Food Res. Int. 2009, 42, 647-652.

26. Hsu, K.C. Purification of antioxidative peptides prepared from enzymatic hydrolysates of tuna dark muscle by-product. Food Chem. 2010, 122, 42-48.

27. Je, J.Y.; Qian, Z.J.; Byun, H.G.; Kim, S.K. Purification and characterization of an antioxidant peptide obtained from tuna backbone protein by enzymatic hydrolysis. Process Biochem. 2007, 42, 840-846.

28. Chotikachinda, R.; Tantikitti, C.; Benjakul, S.; Rustad, T.; Kumarnsit, E. Production of protein hydrolysates from skipjack tuna (Katsuwonus pelamis) viscera as feeding attractants for Asian seabass (Lates calcarifer). Aquacult. Nutr. 2013, 19, 773-784.

29. Jamdar, S.N.; Rajalakshmi, V.; Pednekar, M.D.; Juan, F.; Yardi, V.; Sharma, A. Influence of degree of hydrolysis on functional properties, antioxidant activity and ACE inhibitory activity of peanut protein hydrolysate. Food Chem. 2010, 121, 178-184.

30. Ktari, N.; Jridi, M.; Bkhairia, I.; Sayari, N.; Ben Salah, R.; Nasri, M. Functionalities and antioxidant properties of protein hydrolysates from muscle of zebra blenny (Salaria basilisca) obtained with different crude protease extracts. Food Res. Int. 2012, 4, 747-756.

31. Giménez, B.; Alemán, A.; Montero, P.; Gómez-Guillén, M.C. Antioxidant and functional properties of gelatin hydrolysates obtained from skin of sole and squid. Food Chem. 2009, 114, 976-983.

32. Jridi, M.; Lassoued, I.; Nasri, R.; Ayedi Mohamed, A.; Nasri, M.; Souissi, N. Characterization and potential use of cuttlefish skin gelatin hydrolysates prepared by different microbial proteases. BioMed. Res. Int. 2014, 2014, 461728.

33. Centenaro, G.S.; Salas-Mellado, M.; Pires, C.; Batista, I.; Nunes, M.L.; Prentice, C. Fractionation of protein hydrolysates of fish and chicken using membrane ultrafiltration: Investigation of antioxidant activity. Appl. Biochem. Biotechnol. 2014, 172, 2877-2893. 
34. Onuh, J.O.; Girgih, A.T.; Aluko, R.E.; Aliani, M. In vitro antioxidant properties of chicken skin enzymatic protein hydrolysates and membrane fractions. Food Chem. 2014, 150, 366-373.

35. He, R.; Girgih, A.T.; Malomo, S.A.; Ju, X.; Aluko, R.E. Antioxidant activities of enzymatic rapeseed protein hydrolysates and the membrane ultrafiltration fractions. J. Funct. Foods 2013, 5, 219-227.

36. You, L.; Zhao, M.; Regenstein, J.M.; Ren, J. Purification and identification of antioxidative peptides from loach (Misgurnus anguillicaudatus) protein hydrolysate by consecutive chromatography and electrospray ionization-mass spectrometry. Food Res. Int. 2010, 43, 1167-1173.

37. Chalamaiah, M.; Dinesh kumar, B.; Hemalatha, R.; Jyothirmayi, T. Fish protein hydrolysates: Proximate composition, amino acid composition, antioxidant activities and applications: A review. Food Chem. 2012, 135, 3020-3038.

38. Pownall, T.L.; Udenigwe, C.C.; Aluko, R.E. Amino acid composition and antioxidant properties of pea seed (Pisum sativum L.) enzymatic protein hydrolysate fractions. J. Agric. Food Chem. 2010, 58, 4712-4718.

39. Sarmadi, B.H.; Ismail, A. Antioxidative peptides from food proteins: A review. Peptides 2010, 31, 1949-1956.

40. Rajapakse, N.; Mendis, E.; Jung, W.K.; Je, J.Y.; Kim, S.K. Purification of a radical scavenging peptide from fermented mussel sauce and its antioxidant properties. Food Res. Int. 2005, 38, $175-182$.

41. Chandrasekara, A.; Shahidi, F. Inhibitory activities of soluble and bound millet seed phenolics on free radicals and reactive oxygen species. J. Agric. Food Chem. 2011, 59, 428-436.

42. Chandrasekara, N.; Shahidi, F. Effect of roasting on phenolic content and antioxidant activities of whole cashew nuts, kernels, and testa. J. Agric. Food Chem. 2011, 59, 5006-5014.

43. Zhang, M.; Mu, T.H.; Sun, M.J. Purification and identification of antioxidant peptides from sweet potato protein hydrolysates by Alcalase. J. Funct. Foods 2014, 7, 191-200.

44. Qin, L.; Zhu, B.W.; Zhou, D.Y.; Wu, H.T.; Tan, H.; Yang, J.F.; Li, D.M.; Dong, X.P.; Murata, Y. Preparation and antioxidant activity of enzymatic hydrolysates from purple sea urchin (Strongylocentrotus nudus) gonad. LWT-Food Sci. Technol. 2011, 44, 1113-1118.

45. Nikoo, M.; Benjakul, S.; Xu, X. Antioxidant and cryoprotective effects of Amur sturgeon skin gelatin hydrolysate in unwashed fish mince. Food Chem. 2015, 181, 295-303.

46. Lassoued, I.; Mora, L.; Nasri, R.; Jridi, M.; Toldrá, F.; Aristoy, M.C.; Barkia, A.; Nasri, M. Characterization and comparative assessment of antioxidant and ACE inhibitory activities of thornback ray gelatin hydrolysates. J. Funct. Foods 2015, 13, 225-238.

47. Chi, C.F.; Wang, B.; Wang, Y.M.; Zhang, B.; Deng, S.G. Isolation and characterization of three antioxidant peptides from protein hydrolysate of bluefin leatherjacket (Navodon septentrionalis) heads. J. Funct. Foods 2015, 12, 1-10.

48. Chi, C.F.; Cao, Z.H.; Wang, B.; Hu, F.Y.; Li, Z.R.; Zhang, B. Antioxidant and functional properties of collagen hydrolysates from spanish mackerel skin as influenced by average molecular weight. Molecules 2014, 19, 11211-11230.

49. Li, Z.; Wang, B.; Chi, C.; Gong, Y.; Luo, H.; Ding, G. Influence of average molecular weight on antioxidant and functional properties of cartilage collagen hydrolysates from Sphyrna lewini, Dasyatis akjei and Raja porosa. Food Res. Int. 2013, 51, 283-293. 
50. Chen, H.M.; Muramoto, K.; Yamaguchi, F.; Fujimoto, K.; Nokihara, K. Antioxidative properties of histidine-containing peptides designed from peptide fragments found in the digests of a soybean protein. J. Agric. Food Chem. 1998, 46, 49-53.

51. Reed, T.T. Lipid peroxidation and neurodegenerative disease. Free Radical Bio. Med. 2011, 51, 1302-1319.

52. Siswoyo, T.A.; Mardiana, E.; Lee, K.O.; Hoshokawa, K. Isolation and characterization of antioxidant protein fractions from melinjo (Gnetum gnemon) seeds. J. Agric. Food Chem. 2011, $59,5648-5656$.

53. Conway, V.; Gauthier, S.F.; Pouliot, Y. Antioxidant activities of buttermilk proteins, whey proteins, and their enzymatic hydrolysates. J. Agric. Food Chem. 2013, 61, 364-372.

54. Wang, B.; Wang, Y.M.; Chi, C.F.; Luo, H.Y.; Deng, S.G.; Ma, J.Y. Isolation and characterization of collagen and antioxidant collagen peptides from scales of croceine croaker (Pseudosciaena crocea). Mar. Drugs 2013, 11, 4641-4661.

55. Wang, B.; Gong, Y.D.; Li, Z.R.; Yu, D.; Chi, C.F.; Ma, J.Y. Isolation and characterisation of five novel antioxidant peptides from ethanol-soluble proteins hydrolysate of spotless smoothhound (Mustelus griseus) muscle. J. Funct. Foods 2014, 6, 176-185.

(C) 2015 by the authors; licensee MDPI, Basel, Switzerland. This article is an open access article distributed under the terms and conditions of the Creative Commons Attribution license (http://creativecommons.org/licenses/by/4.0/). 